\title{
Ruch Biblijny i Liturgiczny
}

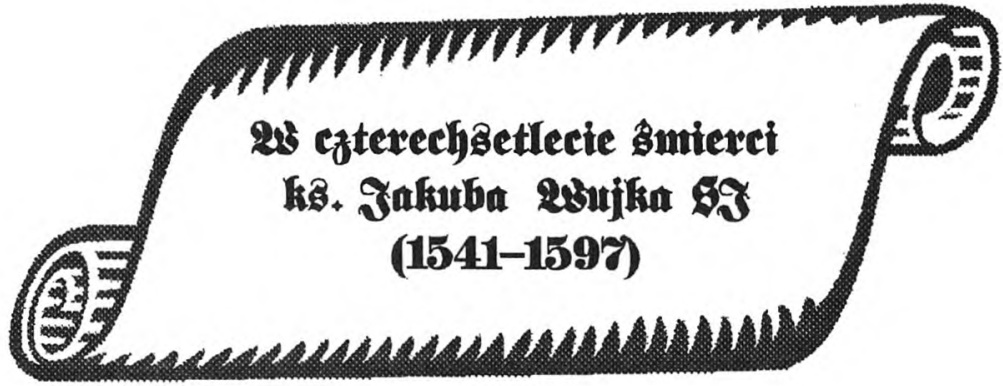

W tym roku 27 lipca minęto 400 lat od chwili, gdy $w$ domu zakonnym św. Barbary w Krakowie oddał ducha Bogu ks. Jakub Wujek SJ z Wągrowca, „zasłużony dla Kościoła i Narodu tłumacz Pisma świętego" - jak głosi napis na tablicy umieszczonej na murze kościoła św. Barbary, w którym został pochowany.

"Upadł jeden filar Kościoła Bożego" - powiedział kaznodzieja pogrzebowy o. Ambroży z Mogilna, kustosz stradomskich bernardynów. Był filarem, ale choć odszedł, pozostawił dzieło trwalsze od spiżu monumentum aere perennius - Biblię polską. "Dał mowie polskiej Pismo święte" - powiedział Prymas Tysiąclecia, kardynał Stefan Wyszyński W Wągrowcu podczas uroczystości poświęcenia nowego pomnika ks. Wujka w roku 1973.

"Czego dokonało niegdyś dla króla siedemdziesięciu męiów, Temu sprostat jeden, thumacząc Biblie święta.

Wujek przełozył Biblie na jezyk sarmacki,

Sprawil to, czego w Egipcie dokonano wysilkiem zbiorowym"

zapisał w swoim Setniku pisarzów polskich ks. Szymon Starowolski. 
Dzisiaj mamy inne, nowe przekłady Biblii, a czas przyniesie jeszcze nowsze tłumaczenia, Jednak Biblia Wujka nie może pozostać li tylko szacownym zabytkiem języka polskiego. Kardynał Karol Wojtyła napisał w stowie wstępnym do jubileuszowego reprintu Wujkowego Nowego Testamentu:

"Sobór Watykański II przez wiele swych dokumentów, zWłaszcza przez Konstytucję o Objawieniu, ale także przez zapoczątkowanie odnowy liturgicznej i ekumenicznej, otworzył dla nas na nowo Pismo święte, a zarazem wywołał nową chłonność na jego jedyną i niepowtarzalną treść. W tym kontekście Biblia ks. Wujka nie posiada wyłącznie znaczenia zabytku z przeszłości, w którym możemy śledzić piękno języka polskiego w jego historycznej postaci. W dziele tym należy natomiast upatrywać coś więcej. Należy w nim widzieć trwały wzór, wedle którego prawda $i$ moc objawionego Słowa Bożego stale odzwierciedla się w naszej ojczystej mowie".

Czterechsetna rocznica śmierci „polskiego semi-Cycerona”, jak nazwali ks. Wujka współcześni, zbiega się $w$ tym roku z sześćsetną rocznicą powstania pierwszego w Polsce Wydziału Teologicznego Akademii Krakowskiej. Ks. Wujek studiował w tej Akademii, spotkał się z wybitnym teologiem i thumaczem biblijnym ks. Janem Niczem Leopolitą, stał się homo trilinguis, co bylo ideałem Renesansu. Jawi nam się dzisiaj - po czterystu latach - ks. Jakub Wujek jako kapłan, teolog, humanista wsłuchany w Stowo Boże. Kiedy umieral, prosił obecnych o wolne czytanie Psalmów. Zmarł wsłuchany w ich przesłanie...

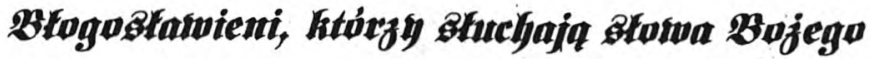 \\ i Btrzegq gp (8K 11, 28)}

ks. Jerzy Chmiel 